\title{
An unusual cause of deranged liver function tests: From paracetamol to Pompe's
}

\author{
Rajkumar Rajendram ${ }^{1 *}$ and Robert Parker $^{2}$ \\ ${ }^{1}$ College of Medicine, King Saud bin Abdulaziz University for Health Sciences, Riyadh, Saudi Arabia \\ ${ }^{2}$ Aintree University Hospital, Liverpool, UK
}

\section{Case report}

We would like to draw to your attention an unusual cause of deranged liver function tests. A 42-year-old woman was admitted following drainage of a dental abscess under general anesthesia. This was uncomplicated but she had accidentally taken a staggered overdose of $10 \mathrm{~g}$ paracetamol for pain. She denied any symptoms and examination was unremarkable.

Blood tests revealed an aspartate transaminase (AST) of $72 \mathrm{iu} / \mathrm{dL}$ and a paracetamol level of $0.06 \mathrm{mmol} / \mathrm{L}$ but were otherwise normal. Twenty four hours later there was no change in the liver function tests and the INR remained 1.1. Hepatitis screen including ferritin, ceruloplasmin, autoantibodies, antimitochondrial antibodies, Hepatitis $\mathrm{A}, \mathrm{B}$ and $\mathrm{C}$ serology and abdominal ultrasound were normal.

She was followed in the hepatology clinic. The AST remained high but there was no change in the other liver function tests. Two years later serum AST isoenzymes were requested. However, these were not routinely performed in the laboratory and the consultant in clinical biochemistry performed creatine kinase (CK; $523 \mathrm{iu} / \mathrm{dL})$ and alanine transaminase (ALT; 44iu/dL) instead.

This suggested that the serum AST originated from muscle rather than the liver. A history of mild generalized weakness was elicited, and examination revealed slightly reduced power $(4 \pm 5)$ and absent reflexes in all four limbs.

Muscle biopsy revealed vacuolation of several myocytes. Periodic acid schiff staining demonstrated glycogen stored within the vacuolated myocytes. The diagnosis of acid maltase deficiency (AMD) was confirmed on enzyme assay.

\section{Discussion and conclusion}

AMD (glycogen storage disease type 2) or Pompe's disease is an autosomal recessive disorder with an estimated incidence of approximately $1: 40,000[1,2]$. There is a deficiency of the enzyme $\alpha 1,4$ glucosidase which breaks down glycogen in cell lysosomes. Glycogen accumulates within lysosomes and disrupts cellular function. This affects skeletal muscle including the diaphragm. The presentation is usually insidious with gradually increasing peripheral muscle weakness or respiratory failure. Prognosis is highly variable and depends on the gene mutation and enzyme activity. As no cure is available, supportive therapies such as noninvasive ventilation and genetic screening of family members are the cornerstones of management. However, enzyme replacement therapies have been developed and the results of initial studies are promising $[3,4]$.

\section{References}

1. Ausems MG, Verbiest J, Hermans MP, Kroos MA, Beemer FA, et al. (1999) Frequency of glycogen storage disease type II in The Netherlands: implications for diagnosis and genetic counselling. Eur J Hum Genet 7: 713-716. [Crossref]

2. Martiniuk F, Chen A, Arvanitopoulos E, Chen Y, Rom WN, et al. (1998) Carrier frequency for glycogen storage disease type II in New York and estimates of affected individuals born with the disease. Am J Med Genet 79: 69-72. [Crossref]

3. Winkel LP, Van Den Hout JM, Kamphoven JH, Disseldorp JA, Remmerswaal M, et al (2004) Enzyme replacement therapy in late-onset Pompe's disease: a three-year followup. Ann Neurol 55: 495-502. [Crossref]

4. Anderson LJ, Henley W, Wyatt KM, Nikolaou V, Waldek S, et al. (2014) Effectiveness of enzyme replacement therapy in adults with late-onset Pompe disease: results from the NCS-LSD cohort study. J Inherit Metab Dis 37: 945-952. [Crossref]
Copyright: (C)2019 Rajendram R. This is an open-access article distributed under the terms of the Creative Commons Attribution License, which permits unrestricted use, distribution, and reproduction in any medium, provided the original author and source are credited.
*Correspondence to: Rajkumar Rajendram, College of Medicine, King Saud bin Abdulaziz University for Health Sciences, Riyadh, Saudi Arabia, Tel: +966 11429 9999; E-mail: rajkumarrajendram@doctors.org.uk

Received: May 23, 2019; Accepted: June 07, 2019; Published: June 12, 2019 